\title{
System Studies of Open-Cycle OTEC Components
}

Brian K. Parsons

Harold F. Link

September 1985

Prepared for Ocean '85

San Diego, California

12-14 November 1985

Prepared under Task No. 4006.31

FTP No. 523

Solar Energy Research Institute

A Division of Midwest Research Institute

1617 Cole Boulevard

Golden, Colorado 80401-3393

Prepared for the

U.S. Department of Energy

Contract No. DE-AC02-83CH10093 


\title{
NOTICE
}

This report was prepared as an account of work sponsored by the United States Government. Neither the United States nor the United States Department of Energy, nor any of their employees, nor any of their contractors, subcontractors, or their employees, makes any warranty, expressed or implied, or assumes any legal liability or responsibility for the accuracy, completeness or usefulness of any information, apparatus, product or process disciosed, or represents that its use would not infringe privately owned rights.

\author{
Printed in the United States of America \\ Available from: \\ National Technical Information Service \\ U.S. Department of Commerce \\ 5285 Port Royal Road \\ Springfield, VA 22161 \\ Price: Microfiche A01 \\ Printed Copy AO2
}

Codes are used for pricing all publications. The code is determined by the number of pages in the publication. Information pertaining to the pricing codes can be found in the current issue of the following publications, which are generally available in most libraries: Energy Research Abstracts, (ERA); Government Reports Announcements and Index (GRA and 1); Scientific and Technical Abstract Reports (STAR); and publication, NTIS-PR-360 available from NTIS at the above address. 


\title{
SYSTEM STUDIES OF OPEN-CYCLE OTEC COHPONENTS
}

\author{
Brian K. Parsons \\ Harold F. LInk \\ Solar Energy Research Inst1tute \\ 1617 Cole Boulevard \\ Golden, Colorado 80401
}

\begin{abstract}
A system model of open Rankine cycle ocean thermal energy conversion (OC-OTEC) was used to examine the effects of component performance and design on plant cost. Three components are examined in deta1l: an opt1onal seawater deaeration subsystem, the flash evaporator, and a two-stage directcontact condenser. Preliminary data quantifying noncondensable gas release in upcomers and a debubbler chamber were used to evaluate the effect of predeaeration (removing the dissolved gases in deaeration chambers before the seawater enters the heat exchangers) on system cost and performance. Little data on the interactions between geometry and performance of vertical spout flash evaporators operating under OTEC conditions are avallable; therefore, we performed Independent parametric varlations. For the direct-contact condenser previous numerical studies provide the basis for coupling geometry and performance. Results of these studies are useful in setting research priorities, in defining operating conditions for further seawater experiments, and In updating plant cost estimates.
\end{abstract}

\subsection{INTRODOCTION}

\subsection{Resource and Technology}

The oceans contain a great amount of stored thermal energy. The temperature. difference between the surface and deep water creates thermal gradients that can be turned into electricity. The conversion technology is simflar to that used in conventional power plants. The sensible energy contained in the warm surface water is used to vaporize a working fluld that is then expanded through a turbine connected to an electric generator. A condenser malntalns low pressure at the turbine exit using cold seawater as the energy sink.

Over a century ago, d'Arsonval ${ }^{1}$ f1rst suggested using ocean thermal gradients to generate power using a closed-cycle system. Th1s system uses a secondary working fluld, such as ammonla, to drive a turbine. Surface heat exchangers evaporate and condense the working fluld whlle separating the working fluld from the seawater. Using a secondary working fluld allows the power cycle to operate at a higher pressure.

In 1930, George Claude, ${ }^{2}$ a student of d'Arsonval, proposed and demonstrated an alternative cycle, the open cycle, that uses steam evaporated directly from the seawater to power a turbine. Since the seawater temperature is less than the normal bolling point at atmospheric pressure, the power cycle pressure must be subatmospher1c. Low pressure at the turbine exit may be malntalned by a surface condenser, which has an added benefit of producing fresh water as a by-product, or by a direct-contact condenser in which the steam condenses directly on the cold seawater.

In 1979, West1nghouse Electric Corporation completed a comprehensive analysis of a $100-\mathrm{MW}$ net floating, open cycle plant for the Department of Energy. The analysis projected that floating plants in the range of $35-100 \mathrm{MW}_{e}$ would be costeffective. The report 1dentifled several technical uncertalntles and unknowns along with thelr potentlal for 1mproving the plant's performance and economic viability. The largest potentlal cost 1mpacts were assoclated with the evaporator, mist removal device, and condenser. Since that time, research at the Solar Energy Research Inst1tute (SERI) and 1ts contractors has addressed these and other 1mportant 1ssues. ${ }^{4-26}$

\subsection{Open-Cycle Systen Description}

A block dlagram of the bas1c open-cycle system 1s presented in F1g. 1. Warm troplcal seawater $\left(\sim 25^{\circ} \mathrm{C}\right)$ is pumped from near the ocean surface Into an evacuated evaporator chamber where the pressure is lower than the corresponding saturation condition of the entering seawater. Flash evaporation results, cooling the seawater and converting a small portion of $1 t(0.5 \%)$ to low-pressure steam.

The cooler seawater $\left(\sim 20^{\circ} \mathrm{C}\right)$ is then discharged back into. the ocean. For some evaporator designs, the bolling process may entrain seawater in the steam, causing corrosion and erosion of the turbine blades. To mitlgate this problem, a mist removal device may be required.

The steam expands through a turbine and a diffuser towards the condenser. A generator connected to 


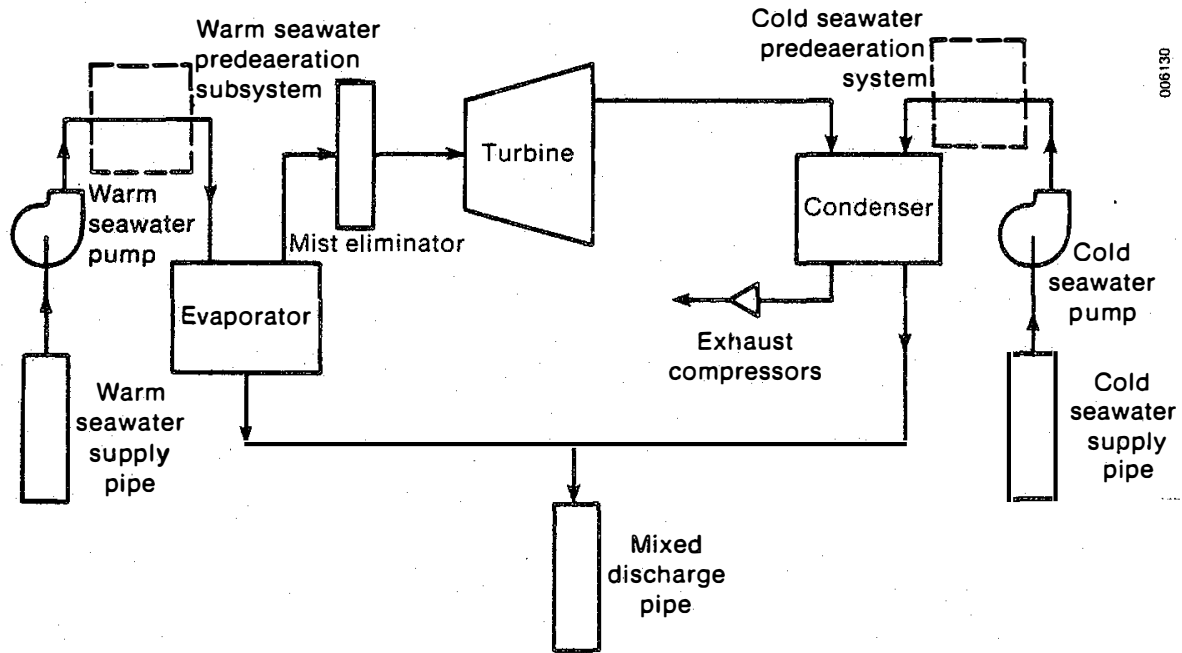

PIG. 1 OPEN RANRINE CYCLE OTEC SYSTEM

the turbine produces the electric power, which also operates the seawater pumps and the exhaust compressors.

Cold seawater $\left(\sim 5^{\circ} \mathrm{C}\right)$ is pumped from depths of around $1000 \mathrm{~m}$ 1nto the condenser to malntaln the condenser pressure. D1ssolved gases, present in the seawater, may come out of solution. To prevent an Increase in pressure and loss in efficlency in the condenser, these gases, along with alr leakage into the vacuum enclosure, must be removed by an exhaust system.

Some of the dissolved noncondensable gases may be removed from the warm and cold seawater before entering the main power system. These optional seawater predeaeration components operate at pressures greater than the seawater vapor pressure but low enough to allow noncondensable gas desorption.

\subsection{Curzent Status}

Recent studles have shown that small-scale, landbased plants can be economic in the short term. The longer seawater supply plpes required by landbased facllities increase parasit1c pumping power and capital cost but ellminate the technical risk and uncertalnty assoclated with mooring or station keeping of large floating structures, dellvery of energy to shore, and the effects of plant motion on the power cycle.

Smaller capacity plants (on the order of 10-50 $\mathrm{MW}_{e}$ ) are expected to penetrate the high energy cost island market in a much shorter time than largecapac1ty plants. In addit1on, many of these 1sland communitles are in need of Increased freshwater supplies. If a surface condenser (1.e., shell and tube or plate-f(n) is used, an OC-OTEC system produces a signiflcant amount of fresh water, nearly $200 \mathrm{~kg} / \mathrm{s}$ (4 million gal/day) for a 10-MW plant. Another factor is that the percelved
Investment risk for a f1rst generation OC-OTEC plant is high. By concentrating research on a smaller plant, whlch would require a much lower total capital investment, the difficulty of financling is lessened. Our research has shown prellminary costs of around $\$ 7200 / \mathrm{kW}$ for a typlcal

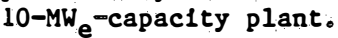

The technical feasibility of OC-OTEC was established when Georges Claude demonstrated the princlples in an operating plant in the 1930s. Numerous studies have addressed the simultaneous heat and mass transfer processes in the directcontact heat exchangers both analytically and experimentally. $4,5,7-9,12,17-22$. These studies have cons1derably Increased our understanding of the candidate geometrles for the evaporator and directcontact condenser. A major limitation at this time is that most experiments have used fresh water. Performance with seawater might be significantly different, and only limited experiments with seawater have been performed.20 The effects of the presence of nucleation sites as well as other differences between fresh water and seawater, such as surface tension, natural surfactants, and bolling polnt elevation, are not well understood.

Performance and l1fe expectancy of the low-pressure turbine is an area of continuing investigation. In their 1979 study and in a follow-up study, Westinghouse 3,24 1dentifled the potentlal for manufacturing very large (45-m) turbines corresponding to a gross power of $140 \mathrm{MW}$. The blade manufacturing concept used composite manufacturing techniques similar to hellcopter rotor technology。 More recently, smaller scale metal blade (1-3 $\mathrm{MW}_{e}$ ) concepts have been presented using conventional low-pressure stage rotors and slightly modifled stators. 25,26 We belleve a turblne of this type could be designed with very little development work. The largest remaining turbine unknown is the amount and the magnitude of the effects of seawater droplets entrained in the steam (which could cause erosion and corrosion of the 
blades). Another issue is off-design point performance and the best control strategy to maintain maximum output.

Seawater pumps and exhaust compressors are ava11able as off-the-shelf 1tems, and little research has addressed these components. Corrosion and maintenance in the seawater environment is a problem, but these issues are not critical and are being examined by manufacturers for many applications.

For 5-10 MW capacity plants the technology exists for manufacturing conventional seawater supply plpes of sufficlent diameter $(2-4 \mathrm{~m})$. However, the dlameter dictated by larger plants would require manufacturing technology development. For relatively small rigid pipes the major remaining unknown is related to deployment. In addition, many issues remaln regarding steep undersea slope stabllity, currents, storms, etc., and their effect on different pipe designs. Several advanced concepts such as undersea drilling and "Inflatable" plpes with a submerged pump can greatly reduce cost to the level of the long-term DOE goal and are currently belng examined. It is beyond the scope of this paper to thoroughly address research in this area, but several critical issues remain.

Currently, the Natural Energy Laboratory of Hawa11 (NELH), located on the west coast of the 1sland of Hawa11 at Reahole Point, is Investigating, many of the research issues associated with OTEC $\$, 20$ with funding from DOE, the state of Hawa11, and private companies. Other projects--for example, mariculture and seawater corrosion--are also beling performed at NELH with both public and private funding. NELH is the only laboratory experimenting with actual seawater. Existing seawater supply pipes deliver around $32 \mathrm{~kg} / \mathrm{s}$ ( $500 \mathrm{gal} / \mathrm{mln}$ ) of cold seawater at $8^{\circ} \mathrm{C}$ and $65 \mathrm{~kg} / \mathrm{s}$ (1000 gal/min) of warm seawater at $26^{\circ} \mathrm{C}$. Future plans include expanding the facility to accommodate critical component and integrated cycle experiments.

\subsection{STSTEM MODEI}

\subsection{General Description}

The computer model of an open-cycle system consists of subroutines that simulate the components shown In F1g. 1. Besides these subroutines the model includes a subroutine that calculates the intercomponent steam pressure losses. The component performance modeling equations are described by Parsons et al.10,14 with the exception of the condense model, which has been updated since these reports. 9 A brief description of the solution method is as follows: four temperatures are chosen at the onset, the warm water inlet, the evaporator steam outlet, the turbine outlet, and the cold water inlet. For a given warm water flow rate the warm water outlet temperature is found from the evaporator effectiveness $(\varepsilon)$ defined as :

$$
\varepsilon=\left(T_{w 1}-T_{w 0}\right) /\left(T_{w 1}-T_{s}\right),
$$

where $T_{W 1}$ is the wann water inlet temperature, $T_{\text {wo }}$ 1s the warm water outlet temperature, and $T_{s}$ is the steam outlet temperature. In this paper we used an IR-100-awward-winning vertical spout evaporator design 27 with a nominal effectiveness of 0.90 . The steam mass flow rate is then found from a heat balance. We can find the noncondensable gas release from the warm seawater from Inlet cond1tions and the input percentage of equilibrium achleved. Alr leakage into the vacuum chamber is Included as an 1nput. Pressure (and corresponding temperature) drops in the mist eliminator ${ }^{6}$ and steam passageways are found using lnput pressure drop coefficlents (" $K$ " factors). With the turbine Inlet temperature, outlet temperature, steam mass. flow rate, and a specifled isentropic efficlency we can compute the turbine power output. By applying a generator efficlency we can find the gross electric power of the plant. A diffuser component converts some of the steam velocity head at the turbine exit into increased steam temperature and pressure using an Input diffuser recovery factor. The condenser model calculates four quantitles: percentage of steam condensed, percentage of dissolved Inert gas release, steam outlet temperature, and vapor side pressure drop for the cocurrent and countercurrent sections from equations derived from the results presented in Bharathan et al. 19 The fitted curves of performance are functions of inlet conditions such as steam temperature, superheat, and noncondensable gas content in the steam plus condenser design conditions such as vapor loading, Jacob number, condenser helght, and 11quid-vapor Interfactal area per unit volume. The cold seawater flow rate is found from the Jacob number, steam loading, and steam temperature. A vent compressor traln.with Interstage coolers then exhausts the uncondensed steam and noncondensable gases to the atmosphere. The power required to run the compressors is subtracted from the gross generator output. In addition, head losses in the seawater supply and discharge pipes are found for specifled pipe lengths and flow velocitles. The model then finds the parasitic pumping power and the net electric output of the plant.

Component sizing is found from flow rates and loadings or velocities. Costs are computed as a function of size using Block et al. 13 and Valenzuela et al. 16 with small modifications, such as Including a cost for condenser fill such as packing or plates associated with a falling film. We then estimate additional costs such as plant design and engineering, land, support bulldings, controls, etc. The Installed power cost in \$/watt is simply the net electric output divided by the total cost. The interested reader may find the detalls of the system model and the coded equations In the earlier listed reference citations. For this study the nominal net installed power value

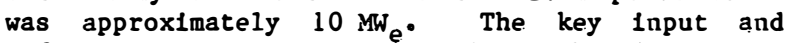
reference parameters are listed in Table 1.

\subsection{Optimization}

The design parameters included in Table 1 correspond to typical OTEC conditions or standard 
Table 1. Constant Plant Parameters

\begin{tabular}{|c|c|}
\hline Component Parameter & Value \\
\hline $\begin{array}{l}\text { Warm seawater flow rate } \\
\text { Warm seawater Inlet temperature } \\
\text { Cold seawater Inlet temperature } \\
\text { Evaporator helght } \\
\text { Evaporator passage } K \text { factor } \\
\text { Mist removal K factor } \\
\text { Turbine passage } K \text { factor } \\
\text { Turbine efficlency } \\
\text { Generator efficlency } \\
\text { Turbline hub-to-tip ratio } \\
\text { Diffuser efficlency } \\
\text { Cocurrent condenser lype } \\
\text { Countercurrent condenser type } \\
\text { Combined compressor and } \\
\text { motor efficlency } \\
\text { Intercooler pressure drop } \\
\text { Compressor pressure ratios } \\
\text { Combined pump/motor efflclency } \\
\text { Warm seawater supply plpe length } \\
\text { Cold seawater supply pipe length } \\
\text { Mixed discharge pipe length } \\
\text { Plpe cost }\end{array}$ & $\begin{array}{c}34620 \mathrm{~kg} / \mathrm{s} \\
25^{\circ} \mathrm{C} \\
5^{\circ} \mathrm{C} \\
0.5 \mathrm{~m} \\
0.5 \\
10.0 \\
1.0 \\
0.8 \\
0.9 \\
0.44 \\
0.9 \\
\text { fall11ng f1lm } \\
\text { packed column } \\
0.72 \\
150 \mathrm{~Pa} \\
1.6 \\
0.78 \\
300 \mathrm{~m} \\
2200 \mathrm{~m} \\
1100 \mathrm{~m} \\
1200 \text { \$/m length } \\
\mathrm{m} \text { diameter }\end{array}$ \\
\hline
\end{tabular}

Industrial component performance and design. These parameters were not varled during optimization studies. Other design parameters (Table 2) may be varied to obtain a minimum installed power cost design. For example, the temperature distribution between components is varied by changing the value of the evaporator steam temperature and the turbine outlet temperature. Another varlable that was examined in the overall optimization was the steam velocity through the mist eliminator. Increasing velocity causes a larger pressure drop (ishich reduces the energy extracted by the turbine), but reduces the area and cost of the device. The other main variables examined in this paper are related to the heat exchanger design conditions.

Geometric design variables such as evaporator spout dlameter, seawater velocity in the spouts, spacing between spouts, and spout helght affect not only the evaporator cost but the structure cost (mainly because of vacuum contalnment size) and seawater pumping power as well. Varying these design parameters will most likely affect evaporator effectiveness, but the coupling between the above geometric varlables and performance is not aval1able. Therefore, we chose nominal conditions for each varlable and did not include evaporator performance and geometry in the overall system optimization. Individual parametric varlations and the nominal values of evaporator varlables are discussed later.

Condenser design parameters affect the system installed power cost by changing the component cost, structure cost, cold seawater pumping power, the pipe design, and vent compressor parameters in a fashion similar to the evaporator design. In contrast to the evaporator, however, we use relations coupling the geometry and 1nlet conditions to the condenser performance. Therefore, overall system optimization includes condenser loadings and geometry as varlables. The geometric variables included in optimization Include gas loading $\left(\mathrm{kg} / \mathrm{s} \mathrm{m}^{2}\right)$, condenser helght, liquid-vapor interfaclal area per unit volume, and a modifled Jacob number defined as:

$$
J a=m_{w} C_{p}\left(T_{w o}-T_{w 1}\right) / m_{s} h_{f g},
$$

where $m_{w}$ is the water flow rate, $C_{p}$ is the specific heat of seawater, $m_{s}$ is the steam flow rate, and $\mathrm{h}_{\mathrm{fg}}$ is the enthalpy of vaporization. Changes in performance and required capital are reflected in the overall system installed power cost.

The final set of parameters included in this optimization determines the seawater supply pipe cost and head losses. For a predetermined water flow rate, the flow velocities of the seawater are varied to determine pipe diameter. Lower velocity decreases head loss and parasitic pumping power while increasing pipe costs. All these parameters are varied until the optimum lowest installed power cost plant is found.

A third category of parameters is also of concern. A large uncertainty exists in the structure costs associated with the vacuum containment vessel. A preliminary estimate was developed $f_{0}$. $10-\mathrm{MW}_{\mathrm{e}}$ land-based plant of $\$ 10,000 / \mathrm{m}^{2} .16$ Depending on the portion of the structure costs that are 1ndependent of planform area and the relation between total planform area and heat exchanger area, the incremental change in siructure cost for small changes in heat exchanger size could vary from around $\$ 5,000$ to $\$ 25,000 / \mathrm{m}^{2}$. Condenser and evaporator studies were performed at both of these values to access the effect of changing the structure cost penalty on optimum design conditions.

Table 2. Plant Paraneters Varled In Optindzation

\begin{tabular}{|c|c|}
\hline Component & Parameter \\
\hline $\begin{array}{l}\text { Evaporator } \\
\text { Turbine } \\
\text { Warm seawater } \\
\text { supply pipe }\end{array}$ & $\begin{array}{l}\text { Steam outlet temperature } \\
\text { Steam outlet temperature } \\
\text { Seawater flow velocity }\end{array}$ \\
\hline $\begin{array}{l}\text { Cold seawater } \\
\text { supply pipe }\end{array}$ & Seawater flow velocity \\
\hline $\begin{array}{l}\text { Mixed discharge pipe } \\
\text { Mist eliminator } \\
\text { Cocurrent condenser }\end{array}$ & $\begin{array}{l}\text { Seawater flow velocity } \\
\text { Steam flow velocity } \\
\text { Helght }\end{array}$ \\
\hline & $\begin{array}{l}\text { Gas loading } \\
\text { Jacob number } \\
\text { Surface area to } \\
\text { volume ratio }\end{array}$ \\
\hline $\begin{array}{l}\text { Countercurrent } \\
\text { condenser }\end{array}$ & $\begin{array}{l}\text { Helght } \\
\text { Gas loading } \\
\text { Jacob number } \\
\text { Surface area to } \\
\text { volume ratio }\end{array}$ \\
\hline $\begin{array}{l}\text { Seawater predeaeration } \\
\text { subsystems }\end{array}$ & Number of stages \\
\hline
\end{tabular}


A similar situation exists with the seawater piping costs. Pipe costs have been estimated at anywhere from $\$ 500$ to $\$ 25,000$ per meter diameter meter length. For the studies presented in this paper we used a value of $\$ 1,200 / \mathrm{m}^{2}$, but additional studies have been performed using pipe costs of $\$ 5,000 / \mathrm{m}^{2}$.

\subsection{Systen Model Uses}

The systems model is used in three principal ways. First, it can be used to 1dentify the opt1mum operating conditions for particular components, such as the condenser or seawater predeaerator. The operating conditions 1dentified in this study are being used to help define experimental conditions for future component tests at NELH. Secondly, the model provides information on the sensitivity of plant cost to varlous unknowns. These sensitivities can be used to rank research issues based on potential cost reductions. Even with uncertainty in the absolute cost predictions, relative differences are easily quantifled. Finally, the model can be used (albelt cautlously) to predict costs and cost-effectiveness of opencycle OTEC plants.

\subsection{PASSIVE SEAHATER PREDEAERATION}

\subsection{Description}

Natural seawater contains a small but significant amount of dissolved noncondensable gases, mafnly nitrogen and oxygen [approximately 15 ppr total ${ }^{23}$ ]. These noncondensable gases come out of solution when the pressure is decreased on the fluid (for example in the evaporator or condenser). A significant parasitic power loss arises from the need to continuously exhaust noncondensable gases from the condenser to maintain the system vacuum. In addition, the presence of noncondensable gases degrades the condensation efficiency. It is possible to remove a portion of the dissolved gases without significant water vapor evolution by exposing the seawater to a pressure higher than the vapor pressure of the water before it enters the heat exchangers. Less power is then required because the desorbed gases are compressed and exhausted to the atmosphere from a pressure higher than the pressure in the condenser. A major factor influencing the desorption rate is the vapor-liquid interfacial area. Active methods for increasing this interfacial area, such as packed columins have been examined in several studies, $3,14,22,28$ but results indicate that the benefits of predeaeration. are counteracted by the additional seawater pumping power required to provide the additional liquid head.

Recent results of experiments at NELH using natural seawater ${ }^{8}$ indicate that these surface area promoting devices may not be required. A significant portion of the noncondensable gases was found to evolve in the supply upcomer for both warm and cold seawater. Figure 2 shows the fraction of equilibrium gas release for nitrogen and oxygen as a function of pressure in a debubbler chamber where the gas was vented to a compressor train. Fraction of equilibrium is defined as:

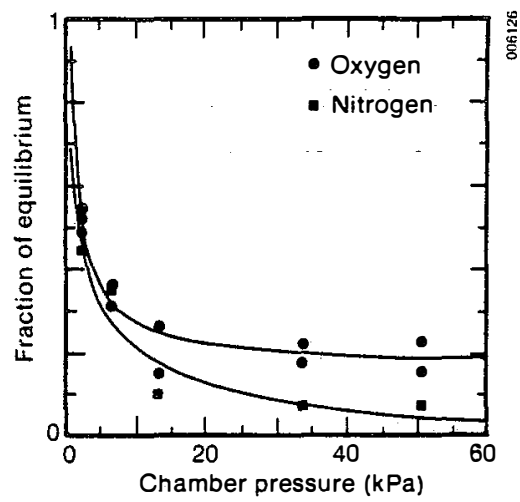

FIG. 2 HAMAII DEAERATION DATA: COLD SEAMATER

$$
f_{e q}=\left(x_{1 n}-x_{\text {out }}\right) /\left(x_{1 n}-x^{*}\right),
$$

where $x_{1 n}$ is the inlet dissolved gas concentration, $x_{\text {out }}$ is the measured outlet dissolved gas concentration, and $x^{*}$ is the equilibrium outlet dissolved gas concentration defined by Henry's law:

$$
x^{\star}=\mathrm{He} \mathrm{P}_{\mathrm{g}}
$$

He is Henry's constant for the gas and is a function of temperature, and $p_{g}$ is the partial pressure of the gas above the 1lquid. The solld ines are data fit to curves used in the predeaeration subsyster model. The use of this data in the open-cycle systems model is preliminary since the mechanisms of gas release are not well understood at this time.

The fitted curves assume that gas release is a function only of chamber pressure. In fact, gas release is probably affected by the presence of nucleation sites, flow velocity, and pipe configuration. More extensive tests will be performed at the NELH including improved instrumentation such as in-line dissolved gas measurements. However, the present data are useful for examining the effects of passive predeaeration on system performance.

\subsection{Seawater Predeaeration Subsysten Model}

The noncondensable gas release curves shown in Fig. 3 were integrated into a seawater predeaeration subsystem model. A schematic of the model is shown in Fig. 4. The deaeration chambers and compressors for removing gases are staged. Referring to the diagram, the seawater first enters deaerator stage $\mathrm{N}$, which is only slightly below atmospheric pressure. A portion of the noncondensable gases is released according to Eqs. 2 and 3. The seawater then progressively enters lower pressure chambers, releasing more gases. The seawater then enters the direct-contact heat exchangers. Because of the predeaeration, much less noncondensable gas is released in the main power cycle vacuum chambers. We assume the seawater head loss assoclated with each deaeration 


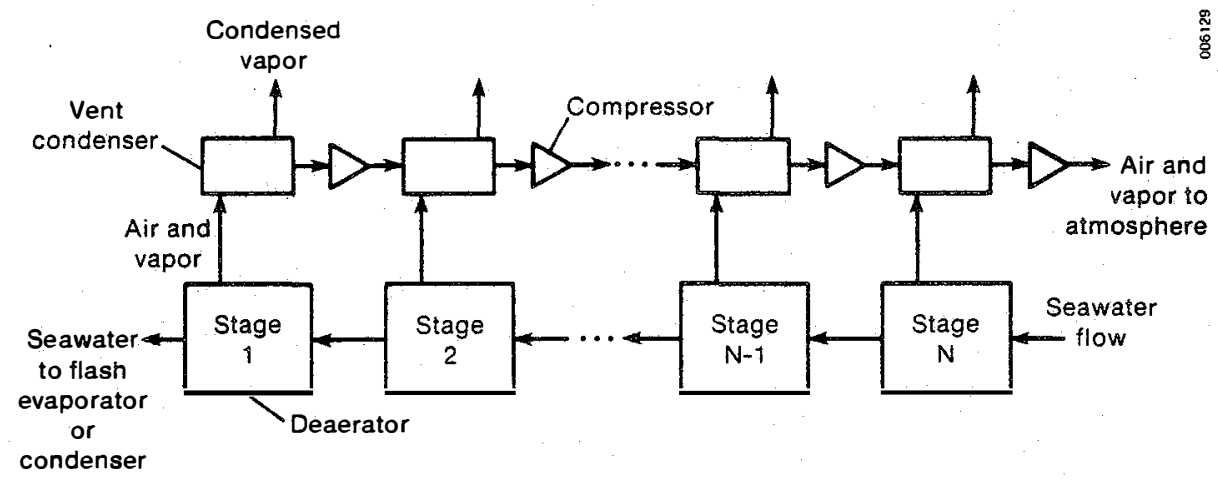

PIG. 3 DEAERATION SUBSYSTEM

stage to be negligible; therefore, we do not need to Increase the seawater pumping power. Staging the deaerators maximizes gas release while minimizing the power requirements of the compressor. Interstage vent condenser and coolers are Included to lower the temperature of the gas exiting a compressor and to reduce the water vapor flow rate in the next compressor. Compressor and intercooler cost equations are Identical to those of the condenser exhaust system. 13 We assume the deaeration chamber cost to be negligible since it only consists of a small gas collection area in the seawater supply stream with a gas venting tap. In the predeaeration studies presented in this paper we used a structure cost of $\$ 25,000 / \mathrm{m}^{2}$ (as discussed In Sec. 2.2).

\subsection{Predeaeration Assuiptions and Results}

System evaluations were made to quantify the effect of adding seawater predeaeration subsystems to the basic OC-OTEC plant. First, we optimized a plant without seawater predeaeration. Then, without changing the parameters that were varled to obtain the optimum plant, seawater predeaeration subsystems were added to both the warm and cold seawater flows. The number of compressor and deaerator stages was systematically increased to

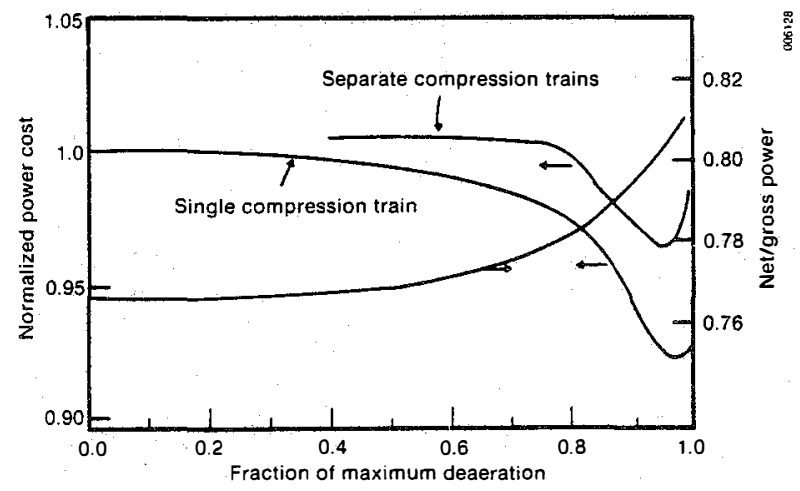

FIG. 4 EFFECTS OF DEARRATION ON SYSTEM PERFORHANCE AND COST change the level of predeaeration. For this paper all the compressor pressure ratios were fixed at 1.6. Larger values of pressure rat1o lead to Increased parasitic power and would not allow us to examine many. levels of deaeration. Smaller pressure ratios are not generally avallable for large volumetric flow rates and may lead to design problems and difficulty in estimating costs. The intercooler vapor pressure drop was set to $150 \mathrm{~Pa}$, which corresponds to values from experimental and numerical studies for an efficlent direct-contact device. 7,19 With this pressure drop and pressure rat1o, the maximum number of stages on the warm side was 7 and on the cold side, 10. Additional stages lead to bolling in the lowest pressure deaerator.

The reduction in normalized installed power cost in $\$ /$ watt and the increase in net/gross power ratio for varlous fractions of maximum deaeration, defined as

$$
\mathrm{F}_{\mathrm{md}}=\left\langle\mathrm{P}_{\mathrm{atm}}-\mathrm{P}_{\mathrm{min}}\right) /\left(\mathrm{P}_{\mathrm{atm}}-\mathrm{P}_{\mathrm{sat}}\right),
$$

where $P_{\text {atm }}$ is atmospheric pressure, $P_{m i n}$ is the lowest deaerator stage pressure, and $P_{\text {sat }}$ is the water vapor pressure, are shown in.Fig. 4. Two cost curves are presented. One is for a single compression train where the vapor from each deaeration chamber is fed into the condenser exhaust compression train at the appropriate points. Another is for separate compression trains for the warm seawater predeaeration subsystem, the cold seawater predeaeration subsystem, and the condenser exhaust subsystem. Separate compression trains may allow for a greater degree of plant control, but costs are increased since the compressor cost versus volumetric flow relation does not have a zero intercept. The use of separate trains does not affect the net power of the plant since power is direcily proportional to vapor flow. A maximum cost reduction of around $7 \%$ $8 \%$ is found at a fraction of maximum deaeration of 0.95. If the plant conditions were reoptimized or the pressure ratios were fine tuned by not assuming a constant value, a further reduction in cost would be realized. Larger fractions lead to increased installed power cost because adding another stage 
Table 3. Effect of Evaporator Geometry on Installed Power Cost

\begin{tabular}{|c|c|c|c|}
\hline Geometric Parameter & Nominal Value & Parametric Range & $\begin{array}{l}\text { Resulting } \\
\text { Normalized } \\
\text { Cost Range }\end{array}$ \\
\hline $\begin{array}{l}\text { Spout height } \\
\text { Spout diameter } \\
\text { Spout seawater velocity } \\
\text { (constant liquid loading) }\end{array}$ & $\begin{array}{l}0.5 \mathrm{~m} \\
0.13 \mathrm{~m} \\
2.0 \mathrm{~m} / \mathrm{s}\end{array}$ & $\begin{array}{l}0.2-2.0 \mathrm{~m} \\
0.05-0.5 \mathrm{~m} \\
0.5-4.0 \mathrm{~m} / \mathrm{s}\end{array}$ & $\begin{array}{l}0.98-1.05 \\
1.01-0.995 \\
0.981 .04\end{array}$ \\
\hline
\end{tabular}

does not significantly reduce the amount of noncondensable gases removed. Unlike previous studies ${ }^{, 22}$ examining active deaeration schemes, this study indicates that including seawater predeaeration subsystems with passive deaerators is worthwhile in OC-OTEC plants because of the ease of gas desorption and the lack of any detrimental liquid head loss. Predeaeration subsystems were used in subsequent optimization studies.

\subsection{EVAPORATOR PARAMETRIC STUDIES AND RESULTS}

Parametric variations of vertical spout evaporator geometry and performance were completed so we could evaluate their effects on normalized installed power cost in $\$ / w a t t$. As mentioned earlier, no interactions between geometry and effectiveness are included in the model. Table 3 lists the nominal condition, parametric range, and effect on normalized installed power cost of several geometric parameters. The nominal plant in this case is an optimized 10-MW plant using the best seawater predeaeration subsystems defined in the study of Sec. 3.

Figure 5 shows the effect of varying the liquid loading and evaporator effectiveness, defined earlfer, on normalized cost. Two sets of curves are presented. The first uses a vacuum structure cost of $\$ 25,000 / \mathrm{m}^{2}$. The effect of liquid loading and evaporator effectiveness on installed power cost is much more pronounced than the effects of

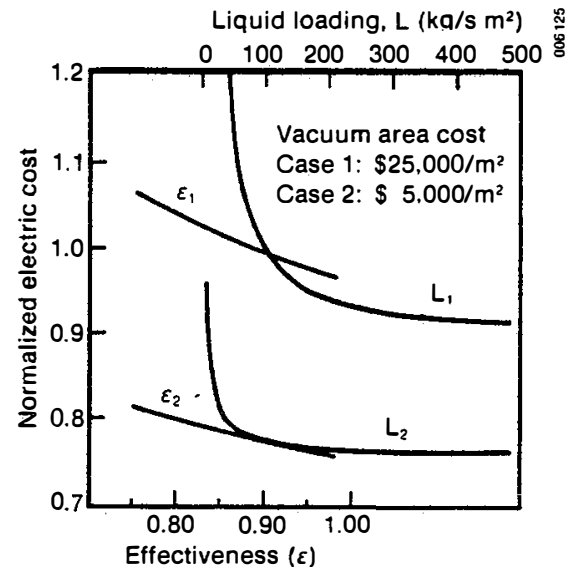

FIG. 5 EFFECTS OF EVAPORATOR PERFORMANCE AND LOADING ON POHER COST the parameters presented in Table 3. Changing the vacuum area cost to $\$ 5,000 / \mathrm{m}^{2}$ significantly reduces the total cost and reduces the effects of these variables. In a practical system liquid loadings greater than $100-150 \mathrm{~kg} / \mathrm{s} \mathrm{m}^{2}$ may lead to severe vapor escape problems.

These parametric studies are useful in defining the variables of importance in evaporator design. They suggest that further seawater experiments should concentrate on verifying the high-effectiveness values obtained in fresh water and the limited seawater tests and on examining the effect of increasing the liquid loading. The height of the spout required to maintain a high effectiveness is also of concern. Once interactions between spout geometry and performance are established, the results will be incorporated into the systems model for further optimization and study.

\subsection{DIRECT-CONTACT CONDENSER STUDIES}

\subsection{Configuration and Model Basis}

The condenser included in these studies is a twostage, direct-contact device schematically shown in Fig. 6. Although surface condensers have also been studied for use in open-cycle OTEC, they are not discussed in this paper. A cocurrent followed by a countercurrent configuration is used. A cocurrent first stage is used for several reasons. In most open-cycle plant designs steam exits the turbine above the barometric level of the condenser efther horizontally or vertically downward. By directing the steam downward the cost and pressure drop associated with a large steam passage to redirect the steam is avoided. In addition, the vapor side pressure drop (which is very important in low driving potential systems like OTEC) of a cocurrent section is low. After a large portion of the steam is condensed $(70 \%-95 \%)$, the steam is turned upward and directed through a countercurrent section. Even though only a small portion of the steam is condensed in the countercurrent section, concentrating the noncondensable gases greatly reduces the exhaust pumping power.

The condenser model used in these studies is derived from results of detalled numerical codes $^{7,19}$ using the Colburn-Hougen 29 approach. Output was compared with results from freshwater condenser experiments with reasonable agreement. Because of the relatively large concentration of noncondensables in the steam, the detalled model evaluates local heat and mass transfer coefficients 


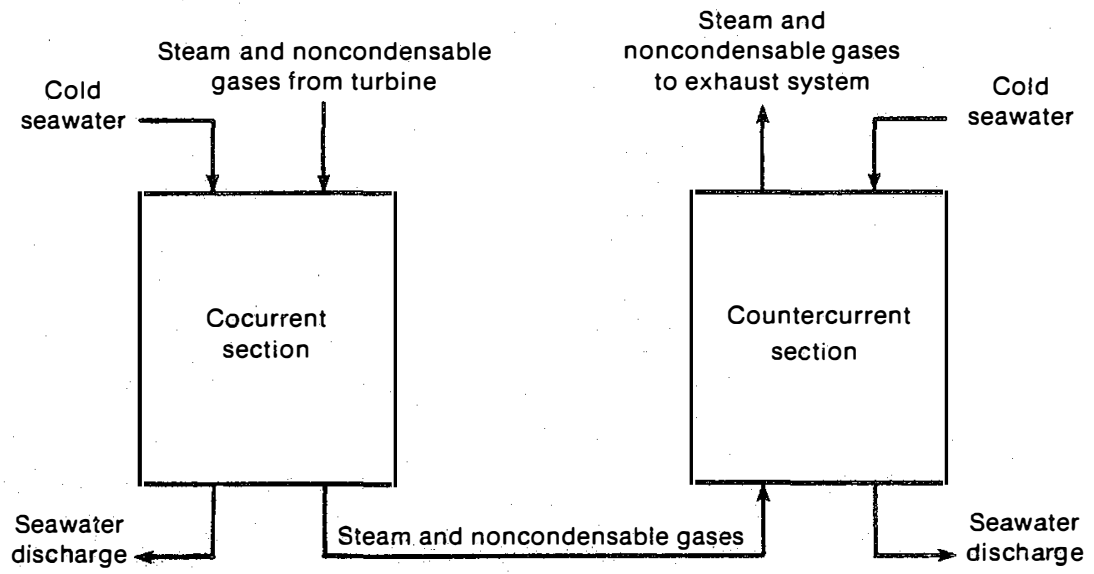

FIG. 6 TWO-STAGE, DIRECT-CONTACT CONDENSER

at discrete intervals. To keep computer costs at a reasonable level integrated results of the detalled numerical model were fit to curves with geometric and design variables as parameters in the systems code condenser subroutine.

\subsection{Assumptions and System Results}

The direct-contact condenser model used in the system studies has several inherent assumptions. The performance fitted curves assume a constant cross-sectional area and interfactal surface area per unit volume. It may be possible to improve performance by talloring these parameters to best fit the local conditions at a given helght in the condenser, but these second-order refinements are not yet included in the code. The code assumes a water distribution and drain collection helght of $0.5 \mathrm{~m}$. For conservative predictions condensation in these areas is not considered. In addition to the piping, floor, and vacuum structure costs discussed in Block et al,, 3 a $\$ 225 / \mathrm{m}^{3}$ charge for packing in the countercurrent section and $\$ 14 / \mathrm{m}^{2}$ for plate plus a water manifold charge for the falling film cocurrent section are included. Steam pressure losses past the water distribution manifold are assumed to be negligible.

Table 4. Comparison of System Operating Conditions for Two Vacuum Area costs

\begin{tabular}{lcc}
\hline & $\$ 5,000 / \mathrm{m}^{2}$ & $\$ 25,000 / \mathrm{m}^{2}$ \\
\hline $\begin{array}{l}\text { Cocurrent section } \\
\text { Height (m) }\end{array}$ & 1.75 & 2.00 \\
Percentage condeised & 91 & 87 \\
Gas loading (kg/s m $)$ & 0.7 & 1.0 \\
Outlet superheat $\left({ }^{\circ} \mathrm{C}\right)$ & 0.8 & 2.1 \\
Countercurrent section & & \\
Height (m) & 2.00 & 2.75 \\
Percentage condensed & 99 & 99 \\
Gas loading (kg/s m $\left.{ }^{2}\right)$ & 0.4 & 0.5 \\
Outlet superheat $\left({ }^{\circ} \mathrm{C}\right)$ & 2.9 & 4.8 \\
\hline
\end{tabular}

We optimized the condenser for the two vacuum area costs used in the evaporator studies. Table 4 compares the resulting condenser design parameters. At higher vacuum area cost the optimum vapor loading is increased in spite of higher pressure losses. In addition, contactor height is increased to make up for a slightly lower condensation effictency. The increased outlet vapor superheat is a result of the larger pressure drop. We also studied the parameters of each design variable to examine the sensitivity of the optima. An example of this procedure is shown in Fig. 7 where normalized installed plant cost is plotted as a function of the cocurrent section height. The relatively low sensitivity of plant cost to cocurretit height allows a trominal height of $1.75 \mathrm{~m}$ to be selected for experiments even without certainty in the structure cost.

These results have been used to define reasonable ranges of design varlables for condenser seawater tests. Verffication of these performance predictions with seawater is crifical. However, if the current model is accurate, condenser design parameters may vary over a fairly wide range without largely affecting installed power cost.

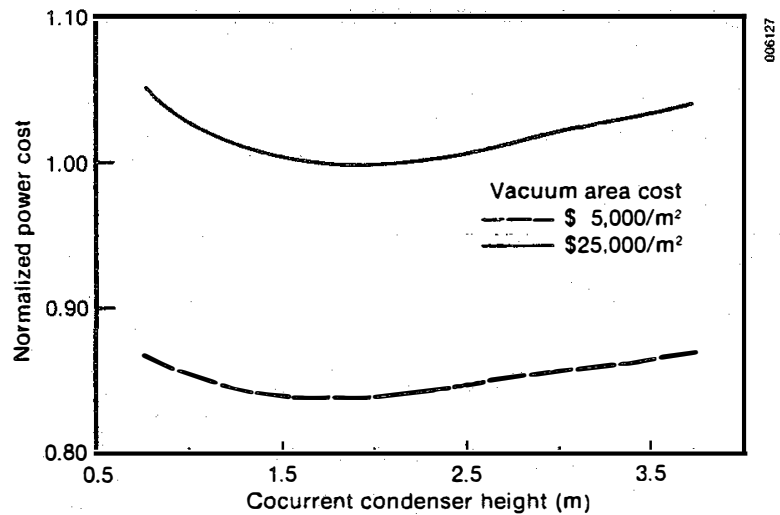

PIG. 7 EFPECTS OF VARPING THE COCURRRNT HEIGHT ON PONER COST 


\subsection{CONCLUSIONS AND RECOMMNDATIONS}

Using preliminary data on the performance of lowhead deaerators quantifles the effect of using seawater predeaeration subsystems on open-cycle UTECInstalled power cost. Reductions 1 in cost of $8 \%$ and an Increase in the net/gross power rat10 of $4 \%$ were demonstrated; further 1mprovements are possible by fine tuning the predeaeration subsystem and reopt1mizing the overall system. The cost difference between using a single compression train and separate compression trains for the warm predeaerators, cold predeaerators, and condenser exhaust was around $4 \%$. It must be emphasized that the data must be verifted and the mechanisms of gas release in these devices must be understood. This could lead to enhancing the performance and Improved overall design.

Parametric studies that varled vertical spout evaporator geometry and performance indicate that the key parameters are maximum liquid loading and evaporator effectiveness. Experiments at NELH will concentrate on verlfying model predictions and establish the needed relations between geometry and performance.

Using the systems model, optimum condenser operating conditions for two structure cost algorithms were 1dentifled. Large varlations in parameters were not observed. These results have been used to define operating conditions for seawater experiments. Sensitfuity of the plant cost to changes in condenser design conditions was generally less than $5 \%$. Future efforts at SERI will include an expanded analytical effort to examine other directcontact condenser geometries and the effects of transfer coefficlent varlations.

There is a critical need for seawater experiments to verify analytical model results, establish relations for interaction that are not addressed in the current models, and examlne component coupling and 1integration effects. Planned future efforts include developing analytical models for additional condenser geometries and component seawater experiments at NELH.

\subsection{ACRNOWLEDGMENT}

We wish to acknowledge and express our gratitude to DOE's Ocean Energy Program, which sponsored this research and to the researchers at NELH for use of their data in the deaeration model.

\subsection{REFERENCES}

1. D'Arsonval, Arsene, "Ut1lisation des forces natuelles: Avenir de L'electricite," La Revue Sclentifique, 17 Sept 1881, pp. 370-372.

2. Claude, Georges, "Power from the Troplcal Seas," Mechanical Engfneering, Vo1. 52, No. 12, December 1930, pp. 1039-1044.

3. Westinghouse Electric Corporation, $100 \mathrm{MWN}$ UTEC Alternate Power Systems, U.S. DOE Contract No. EG-77-C-05-1473, Vol. 1, March 1979.
4. Bharathan, D., Kre1th, F., and Owens, Wo L., "An Overview of Heat and Mass Transfer in OpenCycle OTEC Systems," ASME/JSME Thermal Engineering Jolnt Conference Proceedings, Y. Mor1 and W. J. Wang, eds., Vol. 2, Pp. 301-314, 1983.

5. Bharathan, D., and Penney, T., "Flash Evaporation from Falling Turbulent Jets," ASME/JSME Thermal Engineering Joint Conference Proceedings,

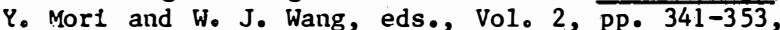
1983.

6. Bharathan, D., and Penney, To, Mist Eliminators for Freshwater Production from Open-Cycle OTEC Systems, SERI/TR-252-1991, Golden, CO: Solar Energy Research Institute, December 1983.

7. Wassel, A. T., Bugby, D. C., M1lls, A。 F。, and Farr, Jo Lo, Jr., "Design Methodology for DirectContact Faliing Film Evaporators and Condensers for Open-Cycle Ocean Thermal Energy Conversion," SAI-083-83R-001, E1 Segundo, CA: Sclence Appl1cations Inc., February 1982.

8. Bharathan, D., Olson, D. A., Green, H. J., and Johnson, D. M., "Measured Performance of DirectContact Jet Condensers," SERI/TP-252-1437, Golden, CO: Solar Energy Research Inst1tute, January 1982.

9. Sam, R. G., and Patel, B. R., "Open-Cycle Ocean Thermal Energy Conversion Evaporator/Condenser Test Program--Data Report," TN-340, Hanover, NH: Creare Research and Development, Inc., October 1982.

10. Parsons, B.P., Bharathan, D., and Althof, J.A., Thermodynamic Systems Aualysis of Open-Cycle Ocean Thermal Energy Conversion, SERI/TR-252-2234, Golden, C0: Solar Energy Research Inst1tute.

11. Penney, T., Bharathan, D., Althof, Jo, and Parsons, B., "Small-Scale, Shore-Based, Open-Cycle Ocean Thermal Energy Conversion Systems-A Design Case Study for an Integrated Research Fac1lity," SERI/TP-252-2331, Golden, CO: Solar Energy Research Institute, forthcoming.

12. Bharathan, D., and Althof, J., "An Experimental Study of Steam Condensation on Water in Countercurrent Flow in Presence of Inert Gases," SERI/TP252-2332, Golden, CO: Solar Energy Research Institute.

13. Block, David L., et al., Thermoeconomic Optimization of OC-OTEC Electriciey and Water plants, SERI Contract No. $X \bar{X}-3-03077-1$, Final Report, September 1984.

14. Parsons, B.K., Althof, J.A., and Bharathan, D., "Open-Cycle OTEC Thermal-Hydraulic Sy'stems Analysis and Parametric Studies," Oceans '84, September 1984.

15. Penney, T., et al., "Open-Cycle Ocean Thermal Energy Conversion (OTEC) Research: Progress Summary and a Design Study," ASME 84-WA/SOL 26, December 1984.

16. Valenzuela, J. A., et al., "Thermoeconomic Analysis of Open-Cycle OTEC Plants," Creare R\&D Inc., ASME 84-WA/SOL-24, December 1984. 
17. Krock, Ho Jo, and Zapka, M. J., "Open-Cycle OTEC Non-Condensable Gas Exchange Characteristics," Intersol '85, International Solar Energy Society Conference, Montreal, Canada, June 1985.

18. Penney, $T_{0} R_{0}$, and Althof, Jo Ao, "Measurements of Gas Sorption from Seawater and the Influence of Gas Release on Open-Cycle Ocean Thermal Energy Conversion (OC-OTEC) System Performance," Intersol 185, International Solar Energy Society Conference, Montreal, Canada, June 1985.

19. Bharathon, Do, Althof, Jo, and Parsons, B., Direct-Contact Condensers for Open-Cycle Ocean Thermal Energy Conversion (OTEC) Applications, Draft Report RR-252-2472, Golden, CO: Solar Energy Research Institute, 1985.

20. Larson-Basse, J., Open-Cycle Ocean Thermal Energy Converston Experiment, Preliminary Report to the Solar Energy Research Institute, Golden, Colorado, 1983.

21. Wasse1, A。 To, Bugby, Do $C_{0}$, and Mills, A. Fo, Bubble Nucleation and Growth in Open-Cycle Ocean Thermal Energy Conversion Subsystems, SAI-08383R-002, Science Applications Inc., 1982.

22. Golshani, Ao, and Chen, Fo $C_{0}$, Ocean Thermal Energy Conversion Gas Desorption Studies, ORNL/Tm7438/V, Oak Ridge National Laboratory, Oak Ridge, $\mathrm{TN}, 1981$ 。
23. Krock, Ho Jo, Gas Analysis of Water Samples for OTEC Program, Technical Report No. 51, J. Ko $K_{0}$ Look Laboratory, University of Hawaif, Honolulu, 1981 .

24. Jennings, So J., "Ocean Thermal Energy Conversion," Open-Cycle Ocean. Thermal Energy Conversion Low-Pressure Turbine Development Program, Dynamic and Off Design Analys1s, Interim Report No. 6, Westinghouse Electric Corp., June 1982.

25. Penney, T., unpublished Letter Report from A. To Wassel, Hermosa Beach, CA: Science Appl1cations, Inc, 14 July 1983.

26. Shelpuk, Bo Co, "A 165-kW Open-Cycle OTEC Experiment," presented at the 12th Annual Intersociety Energy Conversion Engineering Conference 1985, Miami Beach, FL, 18-23 August 1985.

27. Research and Development, October 1984, Barrington, IL。

28. Marchand, Po, "Recent French OTEC Work in the Area of OTEC Systems," 7th Ocean Energy Conference, Washington, DoC., June 1980.

29. Colburn, A。 P., and Hougen, O. A., "Design of Cooler Condensers for Mixtures of Vapors with Noncondensing Gases," Industrial and Engineering Chemistry, Vol。26, ppo 1178-1182, November 1934 . 